\title{
A tribute to Victor A. McKusick
}

$\mathrm{V}$ ictor A. McKusick, MD, University Professor of Medical Genetics emeritus at the Johns Hopkins University School of Medicine, died of cancer on July 22, 2008, at the age of 86. With James Neel and Arno Motulsky, Victor was a founder of the discipline of medical genetics.

Victor had only one earned degree, the MD, from Johns Hopkins in 1946. Because of World War II, he was able to enter medical school after only three years at Tufts University and he referred to himself as a college dropout. He became chief resident of the Osler Medical Service under A. McGehee Harvey, perhaps his most important mentor (1). In 1973, Victor succeeded Harvey as the William Osler Professor of Medicine and physician-in-chief of the Johns Hopkins Hospital. Initially, he pursued cardiology and championed a new technique, phonocardiography. A few years after his appointment as assistant professor in 1954, he published the book Cardiovascular sound in health and disease, which established his clinical and academic reputation. When he surprised his colleagues by deciding to pursue genetics, some suggested he was committing academic suicide. But Victor was intrigued by genetics early in life. First, he was one of monozygotic twins. Second, he was raised on a dairy farm in Parkman,
Maine. His first paper, unfortunately never published, concerned the inheritance of coat color in cattle. Third, as an intern, he cared for several patients with polyposis and pigmented macules on the lips; he collaborated with Harold Jeghers in 1949 on a paper in the New England Journal of Medicine that firmly established recessive inheritance of this condition, originally described by J.L.A. Peutz in 1921. Additionally, as a cardiologist, he encountered patients with Marfan syndrome. Dilatation of the aortic root and aortic dissection were reported a few years earlier by Helen Tausig at Hopkins, among others. In 1955, Victor published a seminal paper in Circulation in which he not only identified the causes of death of dozens of patients with Marfan syndrome but established a new nosology, the heritable disorders of connective tissue. His 1956 monograph on this topic described seven quite distinct disorders that appeared to be associated by primary defects in the extracellular matrix. Eventually, over 200 disorders would be thus classified.

By 1960, he was a full professor and pursued the study of rare disorders full time as director of the outpatient Moore Clinic. He approached the Old Order Amish first as a physician and second as an investigator and thereby identified a host of "new"

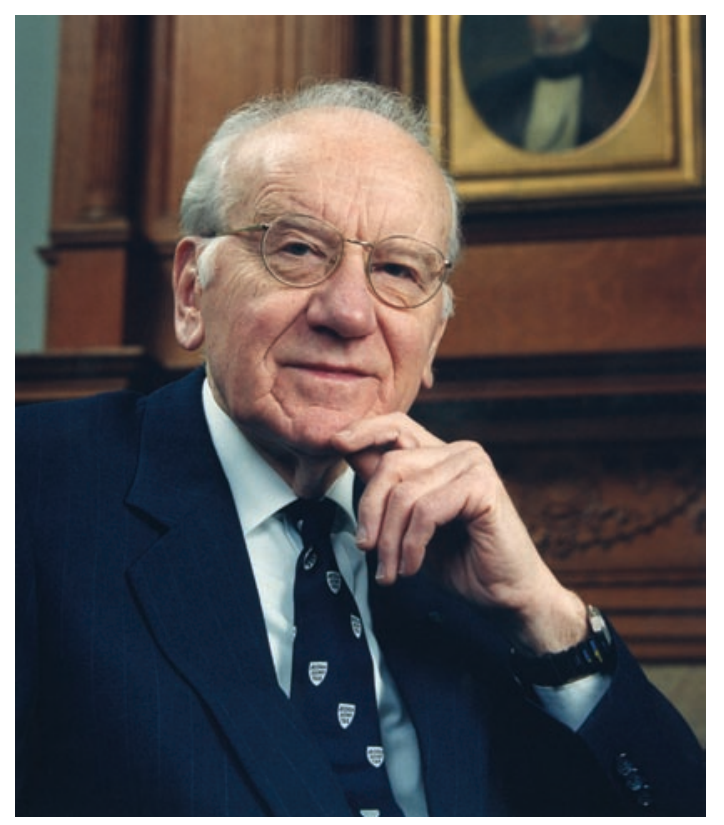

Image credit: Keith Weller, Johns Hopkins Medicine. autosomal recessive syndromes made evident by consanguinity. Always the cataloguer, he established Mendelian inheritance in man (MIM) in 1960. Victor recognized much earlier than most the value of computers and maintained this catalog on magnetic tape, starting in 1964. As one of Victor's trainees, I assisted him in the composition of MIM entries with a first-generation desktop computer and word processing program in 1980. Eventually, MIM morphed into OMIM, the online version now maintained by the National Library of Medicine (2). Nearing 19,000 entries, OMIM remains a vital resource for clinicians and investigators. Victor was also a pioneer in mapping human genes and an early practitioner of linkage analysis in humans. A student of his established the first autosomal linkage, Duffy blood group to chromosome 1, in 1968. Subsequently, Victor helped establish the Human Gene Mapping Workshops, was an early advocate of the Human Genome Project, and was the first president of the Human Genome Organisation. While never self aggrandizing, he was secure in his importance to academic medicine, and a number of personal reflections document his contributions (3-7).

Any homage to Victor must emphasize his mentorship, for which he was greatly respected and beloved. He counted 121 trainees. Some of his earliest trainees are long retired, but those still active and their many "descendants" populate institutions around the world. One enduring legacy began with his 1955 paper on Marfan syndrome and continued when he introduced me to a patient with that condition on my first day at Hopkins as an Osler resident. Together with talented colleagues, we implemented treatments that improved life expectancy to near normal and, in 1991 , discovered the cause of this syndrome. More recently, the first incumbent of the Victor A. McKusick Professorship in Medicine and Genetics, Hal Dietz, discovered the basis of the pathogenesis of this syndrome, which, if it leads to a cure, will be an early triumph of translational medicine. This half-century saga gave Victor tremendous satisfaction. His most powerful - and unspoken - lessons were always the value of persistence and hard work. Virtually no one was his equal. Well into his 80 s, he would be viewing posters at national 
meetings before breakfast, scribbling notes for entry into OMIM later that day. When I incorrectly introduced him as emeritus a couple of years ago, he publicly noted that he was still on the active faculty but only working part time -12 hours a day.

Victor was recognized with 23 honorary degrees, election to the National Academy of Sciences, the Gairdner Foundation International Award, the George M. Kober Medal of the Association of American Physicians, the National Medal of Science, the Albert Lasker Award for Special Achievement in Medical Science, and the 2008 Japan Prize for Medical Genomics and Genetics. Victor was well enough to attend the ceremony in Tokyo in April with Dr. Anne B. McKusick, his wife of nearly 60 years. On his return, he regaled us with tales of the pomp of the ceremony and of dining with the emperor and empress. At the end of the banquet, he spontaneously took the empress' hand to introduce her to his twin, Vincent, the former chief justice of the supreme court of Maine. His eyes twinkled as he recounted how the security detail swiftly intervened in this breach of protocol.

\section{Reed E. Pyeritz}

Division of Medical Genetics, Department of Medicine, University of Pennsylvania Center for the Integration of Genetic Healthcare Technologies, University of Pennsylvania School of Medicine, Philadelphia, Pennsylvania, USA. E-mail: reed.pyeritz@uphs.upenn.edu.
1. McKusick, V.A. 2003. Abner McGehee Harvey, 1911-1998. Proc. Assoc. Am. Phys. 111:365-368.

2. McKusick-Nathans Institute of Genetic Medicine, Johns Hopkins University, and National Center for Biotechnology Information, National Library of Medicine. 2008. OMIM - Online Mendelian Inheritance in Man [database]. http://www.ncbi. nlm.nih.gov/omim/.

3. McKusick, V.A., Naggert, J., Nishina, P., and Valle, D. 1999. 40 years of the annual 'Bar Harbor Course' (1960-1999): a pictorial history. Clin. Genet. 55:398-415.

4. McKusick, V.A. 2001. The anatomy of the human genome: a neo-Vesalian basis for medicine in the 21st century. JAMA. 286:2289-2295.

5. Francomano, C.A., McKusick, V.A., and Biesecker, L.G. 2003. Medical genetic studies in the Amish: historical perspective. Am. J. Med. Genet. 121C:1-4.

6. McKusick, V.A. 2006. A 60-year tale of spots, maps, and genes. Annu. Rev. Genomics Hum. Genet. 7:1-27.

7. McKusick, V.A. 2007. Mendelian Inheritance in Man and its online version, OMIM. Am. J. Hum. Genet. 80:588-604. 